\title{
Introduction: Building a Circumpolar Innovation Agenda
}

Heather Hall, Joelena Leader, and Ken Coates

Governments have almost uniformly concluded that innovation is the key for long-term economic prosperity and for improvements in the quality of life for people around the world (e.g., Prime Minister's Office, Finland 2015; Industry Canada 2017). New and adapted scientific and technological innovations have included, for example, nanofiltration water filters that are producing clean drinking water for people in sub-Saharan Africa, high-speed wireless services for remote parts of Africa, GPS-based navigation systems that are improving transportation systems, social-media powered commercial operations from Airbnb to Uber, and medical technologies embedded in smartphones. However, little of this government supported and private-sector funded innovation effort has filtered through to the Circumpolar World. Northern regions often get later and smaller versions of southern innovations, with very few north-centred developments. For instance, while the Internet is generally available in all but the smallest and most remote communities, it is often characterized by minimal speeds, poor reliability, and extremely high costs (especially in northern Canada, Dobby 2016a; 2016b; FCM 2017). Thus, for the people of the Circumpolar World, the technological revolution has made comparatively few inroads. Equally important, the challenges facing this region have garnered significantly less attention from innovation stakeholders.

Likewise, North America's and Europe's research universities, overwhelmingly near urban centres, receive and spend billions of dollars on nanotechnology, biotechnology, medical sciences, informational technologies, material sciences, environmental machines and systems,

The Northern Review 45 (2017): 1-10

Published by Yukon College, Whitehorse, Canada 
and other research fields that hold enormous promise for continued innovation. With a handful of exceptions - particularly the University of Tromsø and Nord University in Norway; Umeå University and the Luleå University of Technology in Sweden; Finland's University of Oulu and the University of Lapland; the University of Alaska Fairbanks; and the University of Northern British Columbia, Laurentian University, and Yukon College in Canada-northern institutions are comparatively small players in the global innovation economy but significant contributors in the development of the new economy in the North. Even with these efforts, northern regions lag well behind southern and urban areas in capitalizing on innovation opportunities.

Complicating matters more, the academic literature on innovation, which has proliferated over the last several decades, is almost entirely focused on urban centres, leading Isaksen and Karlsen $(2016,277)$ to argue that we need more "empirically based, theoretical reflections about the specifics of innovation activities in [peripheral regions]." Despite northern regions being seen as "'inauspicious' spaces for the dynamic and innovative preconditions of the 'new economy"' (Hall and Donald 2009, 3), the authors in this special collection challenge this prevailing perception while highlighting the significant barriers that require more attention from innovation stakeholders. Using examples from across the Circumpolar North, this collection of work adds geographic diversity to the debates on regional innovation systems, smart specialization, innovation hubs, and measuring innovation.

\section{Circumpolar Innovation Network}

In May 2014, the University of the Arctic established a Thematic Network on the Commercialization of Science and Technology for the North (often referred to as the Circumpolar Innovation Network) under the leadership of Ken Coates, University of Saskatchewan, and Heather Hall, now at the University of Waterloo. Their work was supported, from the beginning, by Emily Neuls and Joelena Leader at the International Centre for Northern Governance and Development, University of Saskatchewan. This thematic network brings together scholars, business leaders, and government officials from across the Circumpolar North, who are interested in understanding northern innovation and mobilizing scientific and technological innovation to address the social, economic, environmental, and cultural needs of the peoples and communities in northern regions.

The Circumpolar Innovation Network held its first formal meeting in association with the Arctic Frontiers meeting in Tromsø, Norway, in 
January 2015. At that meeting, about twenty-five members discussed the issues, questions, and opportunities presented by rapid scientific and technological change. There was clear agreement that more research is needed and, more importantly, that the North needed an activist and engaged effort, designed to bring innovators, business people, government officials, and academics together to determine how best to mobilize new technologies to suit the needs of the North. Further discussions with member institutions demonstrated a strong and shared commitment to ensuring that twenty-first century innovations are developed, at least in part, to match the needs of the Circumpolar North.

Our approach with the Circumpolar Innovation Network is twofold. Our first strategy is to provide a stronger analysis and understanding of contemporary innovation processes in northern regions. The second, and perhaps more important strategy, is to move beyond this analysis and bring participants together to spark circumpolar interest in emerging technologies. The Tromsø meeting made it clear that circumpolar enthusiasm was strong and that individuals and organizations were both concerned about and committed to enhancing the North's innovation capabilities. The leaders of the University of the Arctic's Thematic Network on Circumpolar Innovation determined that a more focused meeting, designed to explore the potential for Far North collaboration on the commercialization of science and technology, was required. Recognizing the need to move at the speed of contemporary innovation, the network organizers collaborated with Yukon College to organize a meeting in Whitehorse, Yukon, in November 2015.

The circumpolar innovation workshop in Whitehorse brought together thirty-eight participants from six countries (Canada, Greenland, Norway, Finland, Sweden, and the United Kingdom). It was supported by the International Centre for Northern Governance and Development (University of Saskatchewan), Yukon College, University of Tromsø, the Arctic University of Norway, and Yukon Economic Development. The format included nine research presentations on the state of innovation in specific circumpolar regions and four panels on the following themes: adapting science and technology for the North; collaboration and northern development; supporting innovation; and innovative approaches to northern development. The panels included leaders from Indigenous communities as well as business leaders and representatives from innovation centres (Leader and Hall 2015). 


\section{Themes in this Special Collection}

This is a collection of five articles that examine innovation in the Circumpolar North as presented at the Whitehorse workshop. The authors are international scholars from multiple disciplines and backgrounds, drawing on examples from around the Circumpolar North including Greenland, Sweden, Finland, Norway, and Canada. This collection of work captures the unique characteristics, challenges, and opportunities that face northern regions in overcoming remoteness, encouraging sustainability, and confronting issues around governance.

For example, in his paper, Adrian Healy discusses the concept of smart specialization in the context of remote circumpolar regions drawing on examples from three areas: Norrbotten County in Northern Sweden; Svalbard in Norway; and the Yukon Territory in Canada. Healy describes how the concept of smart specialization developed in response to the tendency for regions with less advanced research and innovation systems to emulate innovation practices that work in regions with more advanced reseach and innovation, without considering the local context and activities that could build on comparative advantages. He notes that innovation practices in the Circumpolar North are dependent on the "Doing, Using, Interacting" mode of innovation in contrast to a focus on science and technology, which traditional models of innovation are based on. In circumpolar regions, the significance of local conditions, the continued importance of government support, the significance of skills-based initiatives, and the role played by experimentation in the development of new domains of activity are key factors. Healy's findings suggest that proponents of smart specialization can learn from practices in circumpolar regions where entrepreneurial opportunities and innovation activity have largely emerged from building on regional assets, including unique geographic and environmental conditions, to produce highervalue innovation activities. For example, cold climate innovation and technological innovations related to the mining and environmental sectors in the Yukon have produced high levels of innovation activity that has been supported by the Yukon Research Centre at Yukon College. Proponents of smart specialization can also learn from the inclusion of other knowledge systems such as those possessed by Indigenous peoples. The author concludes that an approach based on strategic frameworks that recognize the unique characteristics of innovation in the Circumpolar North could provide the basis for a new model of economic development. 
In her article on innovation in northern Canada, Heather Hall identifies a number of geographic, social, and economic challenges for entrepreneurship, innovation, and economic development including geographic remoteness and isolation, small size and sparse populations, and limited community reinvestment strategies. She highlights the importance of government intervention, the need to build on competitive advantages, and the presence of institutions that support innovation, as illustrated in her example of the mining innovation system in Greater Sudbury in Northern Ontario. She utilizes a Canadian perspective on regional development with insights from regional innovation systems thinking to discuss the unique dynamics of innovation in northern Canada. Hall concludes by identifying opportunities to support innovation and economic development in the North, including through resource development agreements. She also discusses the partnership opportunities needed to support science and technology initiatives in the North and to grow the regional innovation system in northern Canada. Finally, she argues that senior levels of government must be strategic, with a focus on investing in northern and Indigenous communities and developing innovation strategies that prioritize research and public investment for increased capacity and facilitation of interaction between innovation stakeholders.

Håkan Ylinenpää's article highlights the challenges with measuring technological innovation performance using patent data in the peripheral regions of Sweden. He explains how incremental innovations that are "new to the region" or "new to the firm" are often excluded in these measures, despite their potential for creating powerful routes to a more dynamic development path. The author examines two alternative approaches to measure innovation based on Data Envelopment Analysis (DEA) and the Malmquist productivity index, which assist in explaining how different degrees of innovativeness relate to different degrees of economic and social effects. His study illustrates how these alternative approaches are able to better capture technological innovations in the Norrbotten region, the northernmost part of Sweden, where innovation follows its own development trajectory. The author concludes that the concepts of related variety and smart specialization may provide a new pathway for diversifying into new areas, prioritizing knowledge-based investments, and focusing on the strengths and comparative advantages in the Norrbotten region. 
In their article on Arctic innovation hubs, Hintsala, Niemelä, and Tervonen discuss regional innovation policies and practices in three northern European regions: Oulu (Finland), Luleå (Sweden), and Tromsø (Norway). Innovation hubs have been identified as a foundation for generating new business opportunities, operating as global networks to attract investment capital and talent. Their main findings reveal that all three Arctic regions have strong regional centres, adding competitive advantage by fostering interconnections between public policy, academia, and industry. For example, the Lulea region is viewed as a pathway to commercialize research results through direct links into the innovation system. The Oulu region enables university students to link business development activities to their studies by leveraging tuition funds to secure "Business Kitchen" services. Finally, the Tromsø region has the strongest emphasis on the Arctic out of the three innovation hubs, where the cumulative knowledge on multiple Arctic themes demonstrates significant competitive advantages. The authors argue that each northern region could benefit greatly from shared knowledge and the exchange of ideas and experiences, as well as working together through an open communication model for improved outcomes in global competition.

In his article, Christian Wennecke links entrepreneurship and innovation systems theory to the creation of political-economic indicators to assess how Greenland uses and can use political-economic indicators for promoting economic self-sustainability. He identifies how evidencebased governance is emerging and outlines the role that the Greenland government plays in developing workable methods. Wennecke discusses several challenges associated with natural resource projects leading to what is called the "resource curse" and the generation of unfavourable economic development scenarios. In his evaluation of existing politicaleconomic indicators, he found that combining individual and institutional level data provides clearer evidence of the blocking mechanisms to sustainable development. His main findings reveal that, although the potential for a truly self-sustaining economy is unrealistic in the short term, the overall goal will be meaningful in the long term.

\section{Future}

The Circumpolar North faces major challenges in the years ahead and has a great deal at stake in the age of scientific and technology transformation. On the one hand, innovations such as remote mining, drone-driven mineral exploration, and distance education will fundamentally reshape the future of work across the North. Conversely, innovation has the 
potential to address many of the challenges facing the North including access to health services, affordable and locally grown fruits and vegetables, sustainable Arctic energy systems, planning for climate change adaptation, and greatly improved scientific and wildlife monitoring. Innovations could bring about major improvements in northern quality of life but could, equally, produce devastating reductions in jobs and business opportunities. Understanding this complexity, mitigating the negative impacts of innovation, and pursuing innovative solutions to the North's challenges will continue to be the focus of the Circumpolar Innovation Network.

\section{Guest Editors}

Heather M. Hall is an assistant professor in the Economic Development and Innovation Program, School of Environment, Enterprise and Development at the University of Waterloo.

Joelena Leader is a PhD Candidate specializing in northern innovation at the University of Saskatchewan, and was previously a research associate with the International Centre for Northern Governance and Development.

Ken Coates holds the Canada Research Chair in Regional Innovation at the Johnson-Shoyama Graduate School of Public Policy at the University of Saskatchewan in Regina.

\section{References}

Dobby,C.2016a. “CRTCFacesHardTruthsaboutInternetAccessinCanada'sNorth.” GlobeandMail,April11.Accessedfromhttps://www.theglobeandmail.com/reporton-business/crtc-faces-hard-truths-about-internet-access-in-canadas-north/ article29597669/

Dobby, C. 2016b. “Nunavut Plagued by High-Cost, Low-Speed Internet, CRTC Hears." Globe and Mail, April 12. Accessed from https:// www.theglobeandmail.com/report-on-business/crtc-hearsinvestment-needed-to-connect-nunavut-with-high-speed-internet/ article29613527/

FCM. 2017. "Northern Broadband." Accessed from http://www.fcm.ca/home/ issues/northern-and-remote/northern-broadband.htm

Hall, H.M., and B. Donald. 2009. Innovation and Creativity on the Periphery: Challenges and Opportunities in Northern Ontario. Working Paper Series: Ontario in the Creative Age. REF. 2009-WPONT-002.

Industry Canada. 2017. “Innovation for a Better Canada." Accessed from http:// www.ic.gc.ca/eic/site/062.nsf/eng/home 
Isaksen, A., and J. Karlsen. 2016. "Innovation in Peripheral Regions." In Handbook on the Geographies of Innovation, edited by R. Shearmur, C. Carrincazeau, and D. Doloreaux, 277-285. Cheltenham: Edward Elgar Publishing.

Leader, J., and H.M. Hall. 2015. "Highlights from the Circumpolar Innovation Workshop." Whitehorse, Yukon, November 25-27. Accessed from http:// circumpolarinnovation.com/wordpress/wp-content/uploads/2016/02/ Circumpolar-Innovation-Workshop-Report.pdf

Prime Minister's Office, Finland. 2015. Growth from the North. How can Norway, Sweden and Finland Achieve Sustainable Growth in the Scandinavian Arctic? Report of an independent expert group. Helsinki, Finland. Accessed from http://valtioneuvosto.fi/documents/10616/1095776/I0415 Growth+from+the+North net.pdf/2613b2d6-96f8-4ca1-813a-658eaad7f858 